\title{
Revitalization of Tarling arts Islamic Based
}

\author{
Khoirul Fajri ${ }^{1}$, Sumiyadi ${ }^{2}$, Dadang Sunendar ${ }^{3}$, Iskandarwassid ${ }^{4}$ \\ $\left\{\underline{\text { khoirul.fajri@stkipnu.ac.id }}{ }^{1}\right.$, sumiyadi@upi.edu ${ }^{2}$, iskandarwassid@upi.edu $^{4}$ \} \\ $1,2,3,4$ UPI Bandung
}

\begin{abstract}
Tarling is one of the potentials of traditional arts originating from the northern coast of West Java, especially the Indramayu and Cirebon regions. Tarling can be used as an alternative medium for the development of da'wah in pesantren. Traditional elements and communicative nature through their delivery through poetry, narratives, dances and dramatic performances from the performing arts make it easy to use as an effective propaganda media, without losing the element of entertainment. Unfortunately, Tarling's performing arts have not been maximally empowered as a medium for viewing as well as guidance. The role of Tarling as a communication media as a message about the description of the social life of the Cirebon and Indramayu pantura communities by containing messages and moral values is increasingly shrinking. The current of globalization and modernization has led to the emergence of changes in the art of tarling which shows only the entertainment side. Therefore, it needs revitalization, especially the meaning, function and role of developing da'wah in the future so that the role of tarling as an Islamic propagation media can be accepted in all circles, especially in the pesantren area. The purpose of this research is to make the art of tarling as a propaganda media in Islamic boarding schools by revitalizing Islamic tarling based arts. This research is based on a descriptive qualitative research through an ethnographic approach by describing the process of creating the results of revitalization of Islamic-based tarling art which is used as a medium for Islamic da'wah in Islamic boarding schools.
\end{abstract}

Keywords: Revitalization, Value, Function, Tarling, Da'wah

\section{Introduction}

Culture is dynamic. This trait is characterized by the change and development of traditions in accordance with the context and wave of the times. Dynamic culture is a pattern of community life to create a better life from time to time [1]

Murgiyanto states that tradition originates from Latin traditium, meaning everything inherited from the past. [2] Oral tradition becomes a part of local wisdom, a tradition carried out verbally, both already familiar with the script and not familiar with the script. This tradition has local wisdom values that construct the lifestyle and mindset of the people who own it. The oral tradition is not merely a discourse of local culture, but also as a medium for education, socialization of values, and identity of its locality.

The performance art in general does have its function in accordance with the conditions of the community. Jaeni explained that the function of performing arts is as a means of 
ritual, as a personal expression which is generally in the form of personal entertainment, and as an aesthetic presentation.[3]

In the Cirebon area in particular, art forms which are good values of local wisdom that are still accepted by the existence of tarling art. Tarling is better known on the North coast of West Java Island, precisely in the Cirebon area and its surroundings. Tarling is one type of regional art that has unique song characteristics, both in terms of musical composition, song material, and development. That causes quite interesting to be used as material for study and research, in understanding its existence in the supporting community. [4]

The word Tarling comes from the abbreviation of two musical instrument names, namely: guitar, and flute. The meaning of Tarling below is closer to the understanding of Tarling which is more complete, when viewed from the point of view of historical approach and music theory, is as contained in the Indonesian Encyclopaedia, namely:

"Tarling: young traditional music typical of Cirebon, the main musical instruments consist of guitars and flute Abbreviation of gitar and suling is the origin of the Tarling music name. The songs that are played are the pelog tunnels which are self-propelled near to the diatonic scale. In vocal singing, the tuning of the pelog is maintained as accurately as possible. From the ensemble, Tarling eventually became a comedy and simple dances "[5]

The combination of the art of music and drama in tarling art is more identified as the classic tarling or original tarling (Abdurrahman, 2004). The composition of tarling songs is basically a modification of a Gamelan art created and played in the tunes of pelog and laras slendro, for example, Kiser Saedah and Saeni, Cerbonan, and Dermayonan. Tarling songs have a fixed or standard pattern so that they cannot be played withchordsas they are played in pop music. The guitar instrument is played in the form of bass quotes and played using pentatonic gamelan tunes.[6]

As a folk art performance, Tarling has basic performance elements that are the same as traditional folk shows which include drama, dance, and music elements combined withsongs Cirebonan or indramayuan. Tarling became a special art of Cirebon and Indramayu people due to the packaging of music and songs that became the text of the community intertwined with the context faced by the communities of the two regions. [7]

Music Tarling's has undergone a change of form in its development.music Tarling always morphs with other art forms. Because of its always dynamic nature,music Tarling's is still popular with the community. The existence ofmusic Tarling Cirebonhas been able to enrich the musical repertoire in Indonesia.music Tarling Cirebonsince its appearance has always adapted to the demands of the progress of the times. Changes in the order of social life due to technological advances large or small will affect the development ofart Tarling's, however,art is Tarling Cirebonstill in demand by the supporting community, especially the people of Cirebon.

Along with the development of the times, moral values and messages in the art of tarling are increasingly shrinking and more directed to the entertainment and materialistic side only. One factor that continues to change the art of tarling is the influence of the times. The current era of globalization, has a very important role for the development of tarling music. These changes are characterized by a variety of rhythmic types of tarling music, such as: classical, tarling Dangdut, pop, and tarling disco. Classical Tarling by some Cirebon art observers, is considered as identity music and melodic identity of the City of Shrimp (as Cirebon is called). The diversity of tarling music that continues to change and develop in the 
wider community, is feared to reduce the function of identity, and experience form distortions that ultimately are not impossible to be farther away and lose their original form.

Changes in the art of tarling have begun to reduce the function of identity and values as well as the moral message contained in the lyrics of the songs they play, and the plays they show, current developments are more directed to the entertainment side so that Tarling has not been able to keep up with the times still maintain the value and function of the tarling. However, in fact the development of Tarling was so worrying when it was found among the pesantren community to reject the existence of traditional art performances in this case Tarling.

Revitalization is a change in the community because of a new awareness to achieve an ideal or take a way of living with something new or a way of life and values from the past.

The revitalization concept was expressed by Sibarani, who stated that cultural revitalization is a process and effort to digitize culture in people's lives or an effort to make culture become something very important in people's lives. Culture must be part of its supporting community. Local culture must be endeavored to be useful in human life to better prosper the community. [8]

Revitalization of local wisdom has existed since the time of the spread of Islam in Indonesia carried out by the Wali Songo. With crucial significance, Wali Songo in disseminating Islam and fiqh experts in formulating Islamic law considers local wisdom or al'urf. Local wisdom or al-'urf is the core of the tradition of the community that is "recognized" as shared property, is considered appropriate, known for its positive meaning, and proven effective in maintaining the sustainability of the community and keeping it from disturbing elements that can be destructive. [9]

The existence of tarling art can be developed as a missionary media through traditional arts and literature for Islamic boarding schools. This, as a basis for thinking that art and literature can be a learning media for the education of the students in Islamic boarding schools by carrying out boarding schools based on arts and culture.

On this basis, the author will conduct a study entitled "Revitalizing Tarling Art Based on Religion" and answer the problem of how the process of revitalizing the tarling art based on religion.

\section{Research Method}

Methodologically, this study used a descriptive method with a qualitative ethnographic approach. The idea of this research method refers to Spradley [10] and Strauss \& Corbin [11] which states that to reveal the values of local wisdom of a tradition it is necessary to use qualitative ethnographic methods with characteristics of natural background data sources and researchers to function as human instruments.

Fraenkel [12] explains that the concept of ethnographic research that must be understood is the concept of culture, a holistic perspective, contextualization, an emic perspective, thick description (thick description), examination by participants, and non-judgmental orientation. Thus, the data obtained is really able to describe the group of people studied thoroughly and touch various aspects of culture in their lives.

The techniques used in data collection in this study are (1) primary observation, namely direct observation of the art of tarling in Cirebon district; (2) exploratory interviews related to the art of tarling in Cirebon Regency. 
Revitalization study of tarling art in the Cirebon tradition uses a qualitative-interpretive approach with the support of oral and cultural traditions. Moleong synthesizes Bogdan's thinking and Biklen states that qualitative approaches have natural characteristics and are concerned with processes in their research. [13] Based on the focus of the study, the use of oral tradition theory is concerned with the opinion of Danandjaya (1998) which states that research related to folklore can be studied holistically, in the sense that when analyzing it can be related to the background and cultural context of the relevant folklore.

In connection with cultural theory, it is intended to explain the cultural values related to the local wisdom of Cirebon people, which are the object of revitalization in this study.

The results of the revitalization will be demonstrated in the Babakan Ciwaringin Cirebon pesantren research object as a media for da'wah through traditional arts.

\section{Results And Discussion}

\subsection{Whatis Tarling}

Tarling Dangdut Cirebonan which has now penetrated the corners of the archipelago through television, in the beginning wasart fad and not as a spectacle. He is nothing more than village classical music that is used to chat between young people, or as a means of persuasion between them and expressions of heart ravaged by longing for love. [14]

Tarling is a type of Cirebon regional art, characterized by playing guitar and flute music instruments. The music and vocals produced are in pelog. Tarling will always change, as has happened and has been observed in several Tarling artworks / music, since the beginning of its development until now. This shift or change does not only involve music material, but rather a shift in the interests or views of the people of Cirebon towards Tarling music.Art

Dahuriet al explained in detail on the generation round of tarling art, Jayana (circa 1949) was a person who could be considered to be the first figure to collaborate guitar and flute into tarling art to be appreciated and enjoyed by the wider community, and made a spectacle that could produce material[15]

As a folk art performance, Tarling has the basic performance elements that are the same as general folk shows which include elements of drama (drama), dance, and music combined withsongs Cirebonan or indramayuan. Tarling is a special art of Cirebon and Indramayu people due to the packaging of music and songs that are the text of the community that are intertwined with the context faced by the communities of the two regions [16].

\subsection{Revitalizing Tarling Elements Of Music, Song, And Drama Instruments}

Guitar and flute are basic instruments in Tarling music. At the beginning of the development of this music. Tarling consists of 2 guitars and 1 slender flute. Furthermore, this musical ensemble developed with several additions to other musical instruments as a complement or variation in this art.

At present the use of Tarling musical instruments is not limited to guitars, flutes, drums, 'kecrek' / tambourine, goong, and tutukan. The following are musical instruments that can be used to play Tarling music, including: guitar (melody guitar (lead) I, melody (lead) II guitar, bass guitar), diatonic flute, drum (big drum, ketipung), bongo, goong, kecrek, kebluk 
/ tutukan, organs, keyboards, digital drums \& drums, micro composser/ computer music, and others. The researcher revitalized by adding elements of music with khadroh musical instruments with Islamic nuances including: genjring, drumbug, and tambourine. all additions to each instrument are adapted to instruments that are religious in nature and adapted to the times and needs of the song itself.

While in terms of music / songs which usually consist of two forms of Tarling music, namely:

- Music / Tarling Classical

- $\quad$ songs Music / Tarling Irama Cirebon Modern songs (new creations)

In terms of musical rhythm, Tarling music can be classified into several types: Tarling Classic, Tarling Tengdung, Tarling Dangdut, Tarling Pop, Tarling Disco, and Dangdut Disco Tarling.

Tarling Classical song patterns are generally fixed, but in practice it is not always exactly the same, because this type of tarling music gives freedom to improvise. In this song, singers need to be able to be creative and provocative, but not out of the typical Cirebon rhythm and melody pattern.

Additions are in accordance with the revitalization process by adding songs or rhythms of Islamic nuances such as: qosidah or sholawat, prayer, and wangsalan about spirituality.

Whereas in terms of drama there is renewal by telling Islamic stories. Thus the art of tarling can be a religious media that has religious nuances as an objective to apply the values of local wisdom and as a traditional art formulating Islamic law by considering local wisdom in this case is tarling Cirebon.

\section{Conclusion}

Through the revitalization of Islamic-based tarling art is able to restore the values and functions of tarling and restore the structure of previous tarling performances. In addition, through the revitalization of tarling arts can also demonstrate its existence in the traditional performing arts of Cirebon - Indramayu through the renewal of the structure of the performance.

Offsetting the development of modernization among the tarling arts community from the results of revitalization is able to provide its own color by being present as a medium of Islamic da'wah in pesantren education by adding its performance structure, including: a) Khadroh in the structure of music; b) sholawat in song structure; and c) Islamic stories in the structure of drama.

Thus, the revitalization of Islamic-based tarling art can become an Islamic propaganda media that gives the colors of simplicity, traditionalism, and shows the flexibility of the pesantren-based educational culture.

\section{References}

[1] R. Sibarani, Kearifan Lokal: Hakikat, Peran, dan Metode Tradisi Lisan. Jakarta Selatan: Asosiasi Tradisi Lisan, 2012.

[2] D. Murgyanto, Mencermati Seni Pertunjukan (Perspektif Kebudayaan). Surakarta: STSI, 2015.

[3] Jaeni, Kajian Seni Pertunjukan dalam Perspektif Komunikasi Seni. Bogor: IPB Press, 2014.

[4] R. Hidayatullah, "Seni Tarling Dan Perkembangannya," CaLLs, vol. 1, p. 53, 2015. 
[5] V. Hove, Enslikopedi Indonesia. Jakarta: Ikhtiar Baru, 1984.

[6] S. Kasim, "Perkembangan dan Eksistensi Seni Musik Tarling," Cathar. J. Arts Educ., vol. 4, no. 1, p. 53, 2014.

[7] S. Hadi, Warisan Budaya Wangsa Cerbon-Dermayu. Jakarta: Bentara Budaya, 2013.

[8] R. Sibarani, Antropolinguistik: Antropologi Linguistik dan Linguistik Antropologi. Medan: Poda, 2012.

[9] S. Mudji, Reading the Fine Face Culture. Canisius. Yogyakarta, 2014.

[10] Spradley. James P, Doing Participants Observation. Participants Observation. New York: Holt Rinehart and Winston, 1980.

[11] A. S. and Corbin, Basis of Qualitative Research: Grounded Theory Procedure and techniques, vol. 1, no. 1.2015.

[12] J. R. A. N. E. W. Fraenkel, How to Design and Evaluate Reseacrh in Education. New York: McGraw-Hill Compantes, 2007.

[13] M. J., Metodologi Penelitian Kualitatif. Bandung: PT. Remaja Rosdakarya, 2014.

[14] Hatmiati, Pemali dalam Tradisi Lisan Masyarakat Banjar. Malang: PPS Universitas Negeri Malang, 2016.

[15] D. Dahuri, Budaya Bahari: Sebuah Apresiasi di Cirebon. Jakarta: Perum Percetakan Negara RI, 2004.

[16] Jaeni, Kajian Seni Pertunjukan dalam Perspektif Komunikasi Seni. Bogor: IPB Press, 2014. 